Redactie:

Henk van Berkel

Anneke Bax

Desirée Joosten-ten Brinke

Toetsen in het hoger onderwijs 
Redactie:

Henk van Berkel

Anneke Bax

Desirée Joosten-ten Brinke

\section{Toetsen in het hoger onderwijs}

Derde, geheel herziene druk

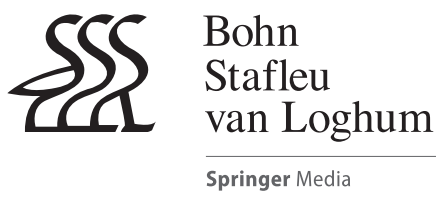




\section{ISBN 978-90-368-0238-3}

(c) 2014 Bohn Stafleu van Loghum, onderdeel van Springer Media BV

Alle rechten voorbehouden. Niets uit deze uitgave mag worden verveelvoudigd, opgeslagen in een geautomatiseerd gegevensbestand, of openbaar gemaakt, in enige vorm of op enige wijze, hetzij elektronisch, mechanisch, door fotokopieën of opnamen, hetzij op enige andere manier, zonder voorafgaande schriftelijke toestemming van de uitgever.

Voor zover het maken van kopieën uit deze uitgave is toegestaan op grond van artikel 16b Auteurswet j het Besluit van 20 juni 1974, Stb. 351, zoals gewijzigd bij het Besluit van 23 augustus 1985, Stb. 471 en artikel 17 Auteurswet, dient men de daarvoor wettelijk verschuldigde vergoedingen te voldoen aan de Stichting Reprorecht (Postbus 3060, 2130 KB Hoofddorp). Voor het overnemen van (een) gedeelte(n) uit deze uitgave in bloemlezingen, readers en andere compilatiewerken (artikel 16 Auteurswet) dient men zich tot de uitgever te wenden.

Samensteller(s) en uitgever zijn zich volledig bewust van hun taak een betrouwbare uitgave te verzorgen. Niettemin kunnen zij geen aansprakelijkheid aanvaarden voor drukfouten en andere onjuistheden die eventueel in deze uitgave voorkomen.

\section{NUR 916}

Ontwerp omslag: Studio Bassa

Automatische opmaak: Crest Premedia Solutions (P) Ltd., Pune, India

Eerste druk 2002

Tweede, herziene druk 2006

Derde, geheel herziene druk 2014

Bohn Stafleu van Loghum

Het Spoor 2

Postbus 246

3990 GA Houten

www.bsl.nl 


\section{Voorwoord}

Alweer een nieuw boek over toetsen in het hoger onderwijs. Maar dan wel één waarvan wij denken dat het een aanvulling is op de bestaande boeken, en niet zozeer een verdubbeling. Het boek gaat in op nieuwe ontwikkelingen op het gebied van toetsen, op vragen van docenten en het bevat veel concrete handvatten.

De belangrijkste reden om dit boek te schrijven, was de roep van docenten om meer informatie over nieuwe ontwikkelingen op het gebied van toetsen. Tijdens onze contacten met docenten bleek dat zij met de gebruikelijke toetsvormen (vooral met meerkeuzevragen) onvoldoende zicht konden krijgen op de kennis, kunde en vaardigheden van hun studenten. Dit heeft vooral te maken met nieuwe doelen die aan onderwijs worden gesteld én met innovatieve onderwijsvormen die een meer aangepaste en authentieke toetsing vergen. Te denken valt hierbij aan het afnemen van toetsen met de computer, de overalltoets, toetsen met portfolio's, voortgangstoetsen, toetsen van competenties en het toetsen van groepsproducten. Deze onderwerpen zijn in het boek opgenomen.

Een andere belangrijke reden voor dit boek is dat er nog steeds veel misgaat bij toetsing en examinering. Uit analyses van tentamens en uit de cursussen die wij voor docenten verzorgen, komen veelvuldig onnodige slordigheden boven tafel bij het construeren van toetsen en bij het formuleren van vragen. Meestal zijn deze makkelijk oplosbaar, mits docenten over de noodzakelijke informatie beschikken. Zo is het bijvoorbeeld met behulp van een werkwoordentabel relatief eenvoudig vragen te formuleren die verder gaan dan het bevragen van reproducerende kennis. Daarnaast is het voor een docent ook eenvoudig de toets te laten voldoen aan de validiteitseis door een specificatietabel te gebruiken. Verder is de kwaliteit van de vragen sterk te verbeteren door de checklists aan te houden die hiervoor bestaan.

Een derde reden is eveneens ontleend aan de praktijk: veel klachten van studenten hebben te maken met de beoordeling, de wijze van nakijken, de zak/slaaggrens en de beslissingen die over hen worden genomen. Ook voor deze problemen bestaan relatief eenvoudige oplossingen. Het hanteren van een antwoordmodel bijvoorbeeld, voorkomt al veel problemen.

Toetsen zijn vrijwel nooit honderd procent perfect, waardoor er ook altijd onzuiverheden in de beoordeling zullen zitten. De manier van het toekennen van cijfers houdt daar nauwelijks rekening mee. Het is nodig dat docenten zich realiseren dat het helemaal niet zo 'zeker' is dat een 5,5 echt een 5,5 is, maar dat een 5,5 net zo goed een 5,4 of 5,6 had kunnen zijn; de zekerheid van terecht zakken of slagen heeft niet altijd een stevige basis. 
Het idee voor dit boek is ontstaan naar aanleiding van ons vorige boek, Beoordelen in het onderwijs, een handleiding voor het construeren van toetsen en het evalueren van leerdoelen en onderwijsvormen (1993). In dat boek worden diverse nieuwe toetsinstrumenten - waaraan onder docenten behoefte blijkt te bestaan - echter niet behandeld. Daarom is in plaats van een herdruk, gekozen voor een geheel nieuwe opzet. Voor ieder hoofdstuk zijn een of meer auteurs benaderd die deskundig zijn op het betreffende gebied. Wij danken alle auteurs voor hun bijdragen.

Januari 2002

\section{- Bij de tweede druk}

Toetsing in het hoger onderwijs staat volop in de belangstelling. De NederlandsVlaamse Accreditatie Organisatie (NVAO) heeft recentelijk uitgesproken dat de wijze waarop opleidingen nadere invulling geven aan toetsen een speerpunt zal zijn bij het beoordelen of opleidingen aan de accreditatie-eisen voldoen. Dat impliceert dat opleidingen (nog) meer aandacht moeten geven aan de manier waarop studenten worden getoetst. Sinds het verschijnen van dit boek in 2002 zijn er ook andere ontwikkelingen die een geactualiseerde druk nodig maken.

Studenten die in het vwo met het studiehuis in aanraking zijn gekomen, hebben inmiddels het hoger onderwijs bereikt (en soms alweer verlaten). Op het vwo hebben zij bijvoorbeeld geleerd werkstukken te maken met behulp van bronnen van het internet. Daar is niets op tegen, mits zij niet zomaar teksten van het internet halen en de suggestie wekken dat ze er zelf de auteur van zijn. Dat zou plagiaat zijn; bronvermelding is een vereiste. Het raadplegen van het internet heeft in het algemeen, onder alle scholieren en studenten, een hoge vlucht genomen. Alleen schort het er nogal eens aan om de bronvermelding op juiste wijze toe te passen. Het brengt studenten ook hoe langer hoe meer in de verleiding andermans werk voor eigen werk uit te geven, hoewel dit soms uit onwetendheid gebeurt. Om het docenten mogelijk te maken na te gaan of er sprake is van plagiaat, is hoofdstuk 21 toegevoegd dat gaat over het opsporen van plagiaat.

Verder heeft de bachelor-masterstructuur ('bama') in het hoger onderwijs haar intrede gedaan. Hoewel de bama in het wetenschappelijk onderwijs wordt gezien als één geheel de overgrote meerderheid van afgestudeerde bachelors gaat door voor master - zal het niet lang meer duren dat een universitaire bachelor het eindstation is van een opleidingsperiode. Dit naar het voorbeeld van de ervaringen in Angelsaksische landen. Studenten met een bachelordiploma gaan daar bijvoorbeeld eerst een bepaalde periode werken om vervolgens alsnog te kiezen voor een mastersopleiding, maar dat kan dan problemen geven voor toelating omdat geleerde kennis verouderd blijkt te zijn. Inmiddels is in het onderwijs steeds meer sprake van life long learning en ervaringskennis. De zogenaamde EVC-procedure (Erkenning Verworven Competenties) is een methode om ervaringskennis in kaart te brengen en te relateren aan de instroomeisen. Daarom is hoofdstuk 22, Toetsen met EVC, aan de tweede druk toegevoegd. 
Vooral binnen het hbo is een toenemende mate van vraaggestuurd en competentiegericht onderwijs te zien. Doelstellingen zijn geformuleerd in termen van beroepscompetenties en authentieke (levensechte) beroepstaken, en praktijksituaties vormen de basis van een curriculum. Naast toetsvormen als (performance)assessments, peer- en coassessment zijn ook de meer traditionele toetsvormen (waaronder kennistoetsen met meerkeuzevragen) van belang, maar met een andere toepassing. Kennis is juist een voorwaarde om competenties te kunnen verwerven, waarbij het er vooral om gaat kennis te gebruiken in een beroepscontext. Dit alles heeft vergaande implicaties voor toetsing, kwaliteitscriteria en beoordeling. In het nieuwe hoofdstuk 23 worden deze aspecten beschreven.

Behalve dat drie nieuwe hoofdstukken zijn toegevoegd zijn sommige hoofdstukken sterk geactualiseerd, in de tekst maar ook in de geannoteerde literatuur achteraan.

\section{Amsterdam/Heerlen, Anneke Bax \\ Maastricht, Henk van Berkel \\ Juni 2006}

\section{- Bij de derde druk}

'Toetsing in het hoger onderwijs staat volop in de belangstelling.' Deze zin stond ook al in het voorwoord bij de tweede druk, in 2006. Toch is de inhoud van dit boek nog steeds actueel, zelfs meer dan in het verleden. De kwaliteitscontrole van het hoger onderwijs wordt, namens de overheid, uitgevoerd door de Nederlands-Vlaamse Accreditatie Organisatie (NVAO). Die hanteert hierbij richtlijnen, ook wel standaarden genoemd. Een van die standaarden is:

\section{I) Standaard 3:}

De opleiding beschikt over een adequaat systeem van toetsing en toont aan dat de beoogde eindkwalificaties worden gerealiseerd. «

In de toelichting staat:

॥ Het gerealiseerde niveau blijkt uit de tussentijdse en afsluitende toetsen, de afstudeerwerken en de wijze waarop afgestudeerden in de praktijk of in een vervolgopleiding functioneren. De toetsen en de beoordeling zijn valide, betrouwbaar en voor studenten inzichtelijk. «

Indien niet aan deze standaard is voldaan, verliest de opleiding haar accreditatie. Vroeger was het nog mogelijk een eventuele onvoldoende voor het toetssysteem te compenseren met positieve oordelen over andere aspecten. Tegenwoordig is dat onmogelijk. Het is dus voor een opleiding gewoon een halszaak om haar toetsingssysteem op orde te hebben.

De redactie heeft gemeend bij het uitgeven van de derde druk de inhoud van het boek kritisch tegen het licht te houden. Zijn alle hoofdstukken nog wel relevant? Moeten er 
geen nieuwe bij? Is de inhoud van sommige hoofdstukken nog wel actueel genoeg, of is aanpassing nodig om nieuwe ontwikkelingen te schetsen? Inderdaad, sommige hoofdstukken waren niet meer actueel - onder andere de overalltoets en vraaggestuurd competentiegericht maatwerkonderwijs komen nauwelijks meer voor in het hoger onderwijs. Andere onderwerpen zijn daarentegen wel sterk in opkomst: toetsbeleid, formatief toetsen, rubrics, onderzoekvaardigheden, (generieke) competenties en landelijke kennistoetsen. Daaraan zijn nieuwe hoofdstukken gewijd. Alle resterende hoofdstukken zijn zo veel mogelijk aangepast aan de actualiteit, maar ook op basis van reacties van lezers.

De redactie is uitgebreid met Desirée Joosten-ten Brinke. Zij is universitair hoofddocent bij de Open Universiteit en lector Eigentijds toetsen en beoordelen aan de Fontys lerarenopleiding in Tilburg.

Amsterdam, Anneke Bax

Landgraaf, Desirée Joosten-ten Brinke

Maastricht, Henk van Berkel

September 2013 


\section{Inhoud}

Het toetsproces ontleed.

Henk van Berkel, Anneke Bax en Desirée Joosten-ten Brinke

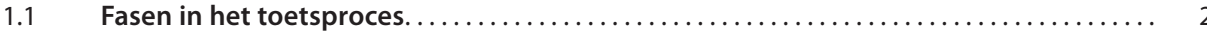

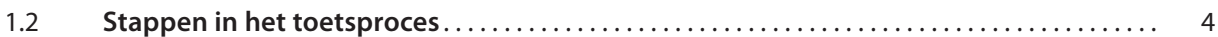

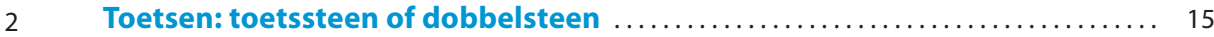

Henk van Berkel en Anneke Bax

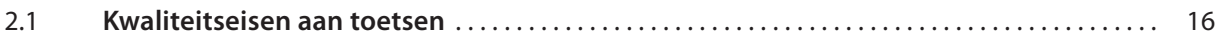

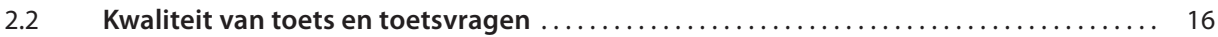

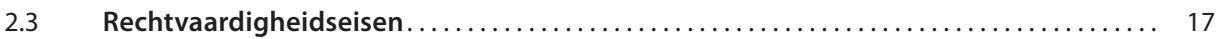

$2.4 \quad$ Psychometrische analyse: het berekenen van indicatoren . . . . . . . . . . . . . . . 19

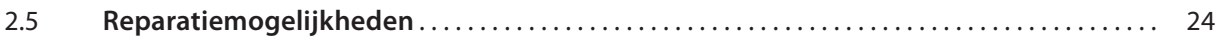

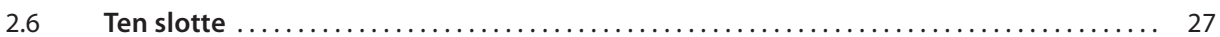

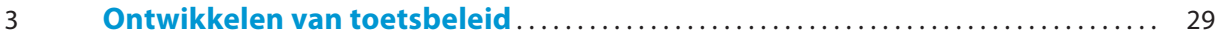

Riet Martens en George Moerkerke

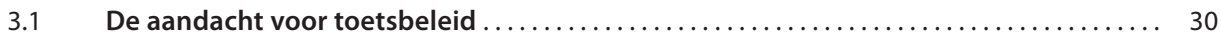

3.2 Integraal toetsbeleid: een samenhangend stelsel $\ldots \ldots \ldots \ldots \ldots \ldots \ldots \ldots \ldots \ldots \ldots \ldots$

3.3 Toetsbeleid en kwaliteit van toetsing op de verschillende organisatieniveaus ...... 33

$3.4 \quad$ Borging van kwaliteit van tentamens en examens door de examencommissie. . . . . 37

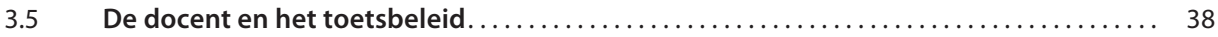

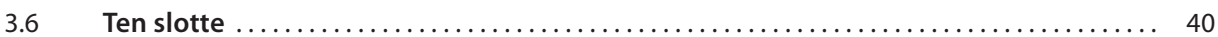

$4 \quad$ Toetsen met landelijke kennistoetsen $\ldots \ldots \ldots \ldots \ldots \ldots \ldots \ldots \ldots \ldots \ldots \ldots \ldots$

Arnoud van Leuven en Wim Lansu

4.1 Waarom een landelijke kennistoets: de gemeenschappelijke kennisbasis ....... 42

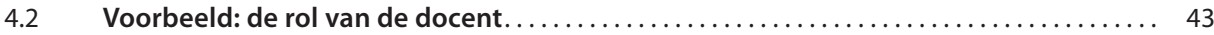

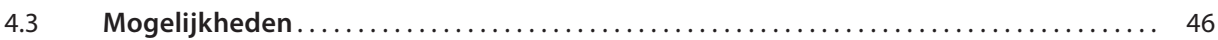

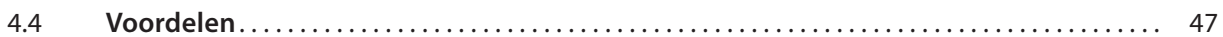

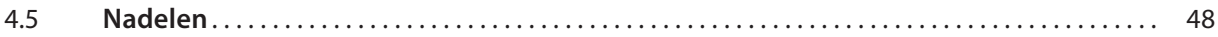

4.6 Voorwaarden voor een succesvolle toepassing ......................... 49

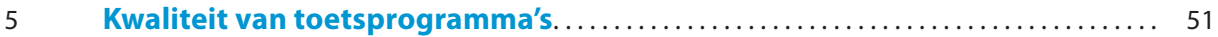

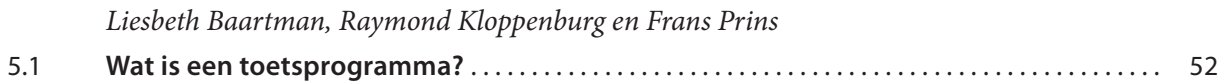

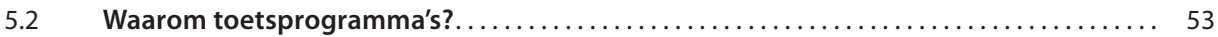

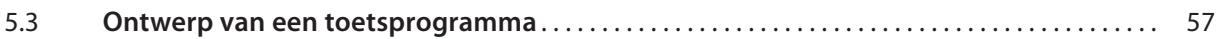

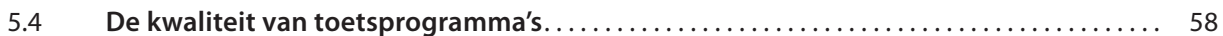

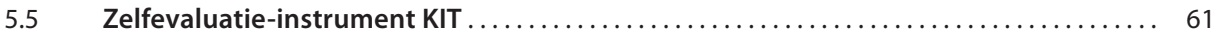

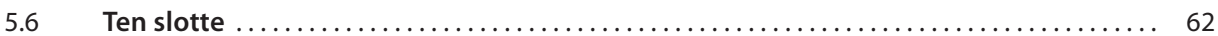


Henk van Berkel

Voorkomen is beter dan genezen.

Programma's voor het opsporen van plagiaat

Henk van Berkel en Wynand Wijnen

$7.1 \quad$ Twee methoden van normeren: relatief en absoluut....................... 74

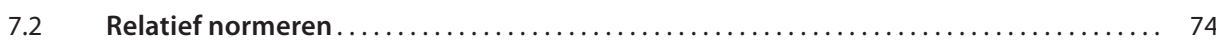

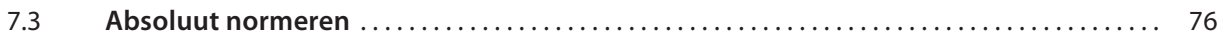

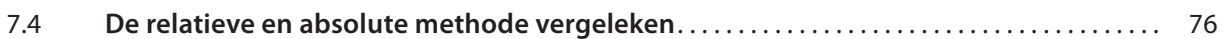

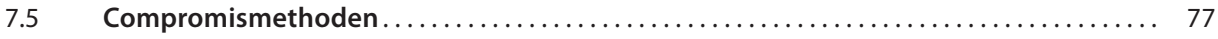

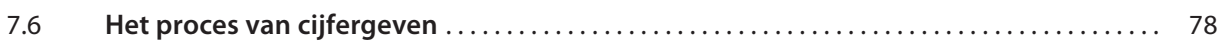

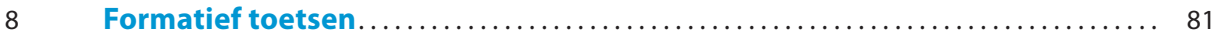

Desirée Joosten-ten Brinke en Dominique Sluijsmans

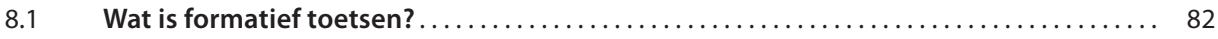

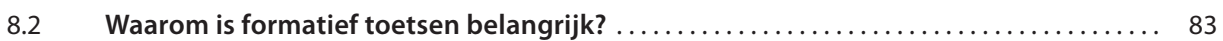

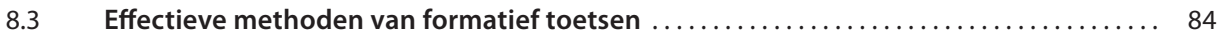

8.4 De rol van docenten bij formatief toetsen ............................. 88

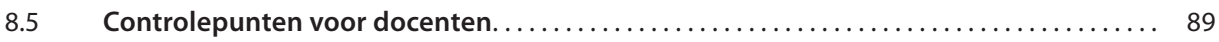

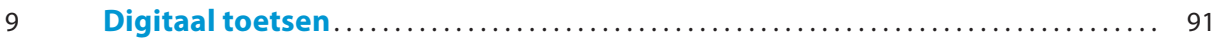

Silvester Draaijer, Patris van Boxel en Marcel van Brunschot

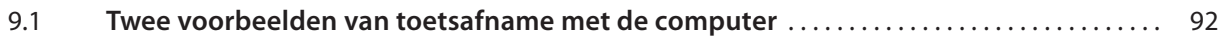

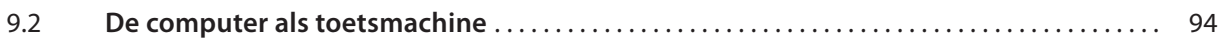

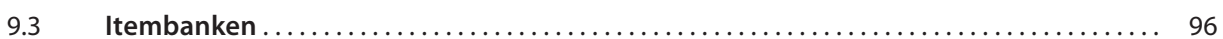

$9.4 \quad$ Nakijken van open vragen en werkstukken $\ldots \ldots \ldots \ldots \ldots \ldots \ldots \ldots \ldots \ldots \ldots \ldots \ldots \ldots \ldots \ldots \ldots \ldots \ldots$

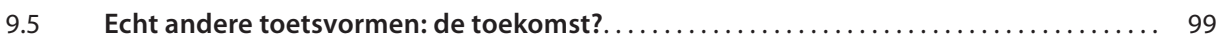

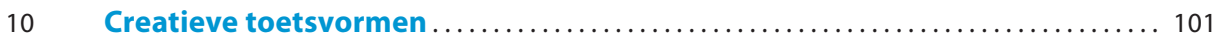

Titus Geerligs, Henk Schmidt, Irma Kokx, Erik de Graaf en Henk van Berkel

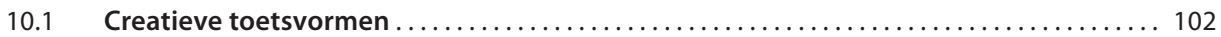

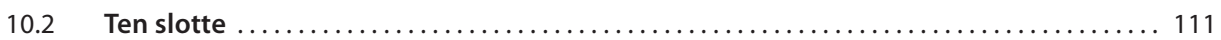

11 Toetsen met gesloten vragen .................................. 113

Henk van Berkel en Anneke Bax

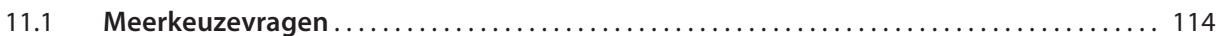

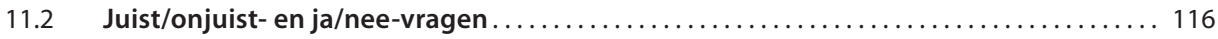




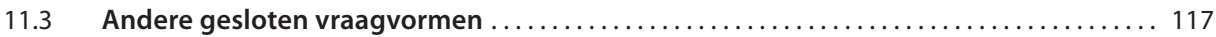

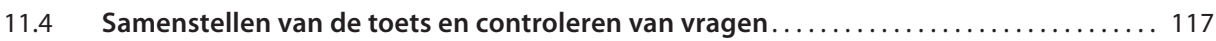

11.5 Toetsen van hogere cognitieve vaardigheden met gesloten vragen ............. 119

11.6 Aanwijzingen en tips voor het construeren van gesloten vragen . . . . . . . . . . 122

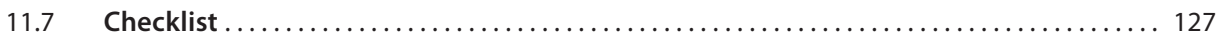

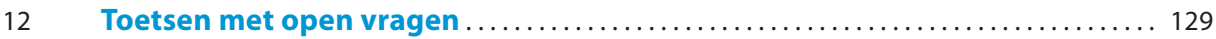

Tom Erkens

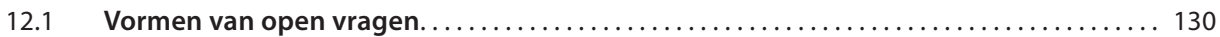

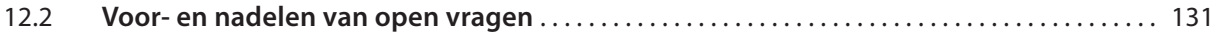

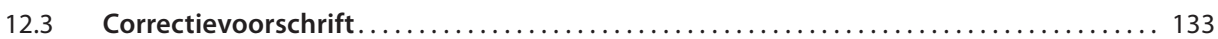

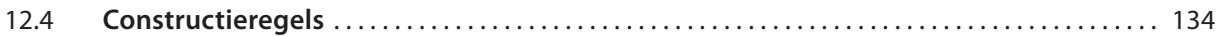

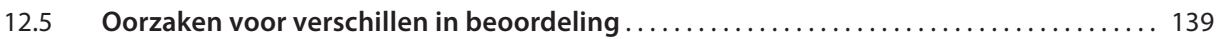

12.6 Oplossingen voor beoordelaarsverschillen ............................ 140

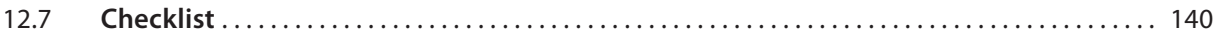

13 Toetsen met korte casussen $\ldots \ldots \ldots \ldots \ldots \ldots \ldots \ldots \ldots \ldots \ldots \ldots \ldots \ldots \ldots \ldots \ldots$

Lambert Schuwirth

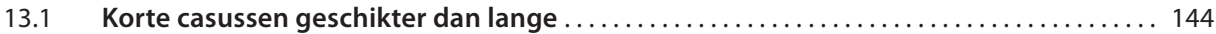

13.2 Construeren en beoordelen van een korte-casustoets . . . . . . . . . . . . . . . . . 145

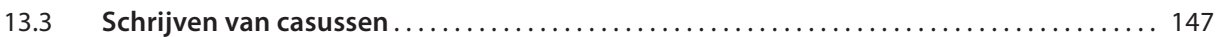

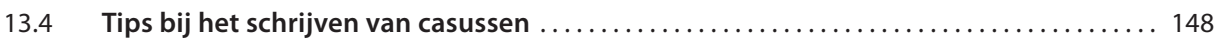

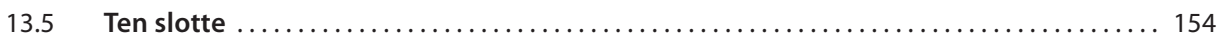

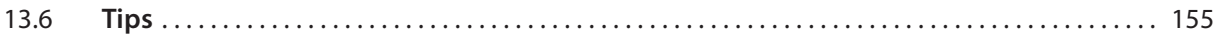

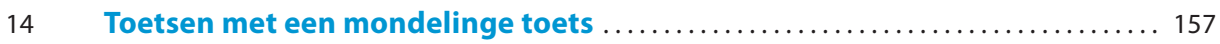

Henk van Berkel en Anneke Bax

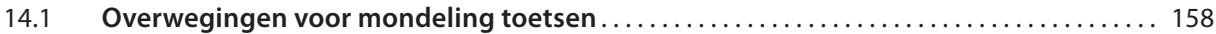

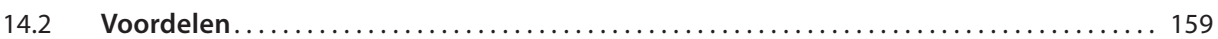

14.3 Kwaliteitseisen voor de beoordeling en haalbaarheid $\ldots \ldots \ldots \ldots \ldots \ldots \ldots \ldots \ldots \ldots$

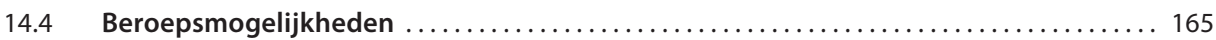

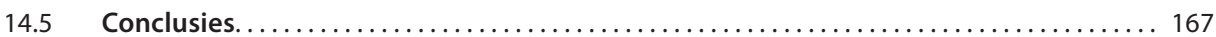

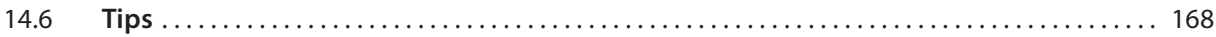

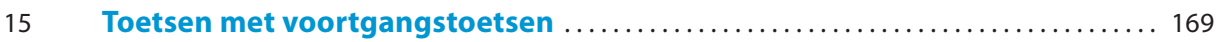

Arno Muijtjens en Wynand Wijnen

$15.1 \quad$ De rol van de docent bij voortgangstoetsing $\ldots \ldots \ldots \ldots \ldots \ldots \ldots \ldots \ldots \ldots \ldots \ldots \ldots$

15.2 Een voorbeeld: de interuniversitaire Voortgangstoets Geneeskunde (iVGT) . . . . .. 171

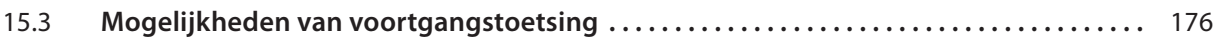

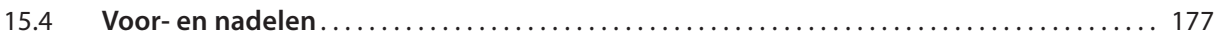

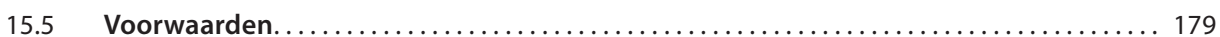

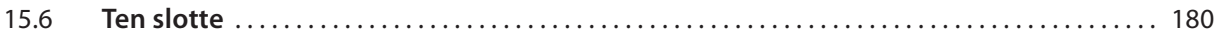


Gerard Straetmans

16.1 Inleiding

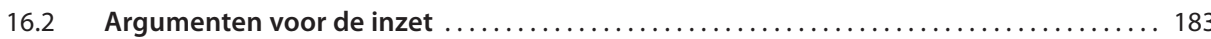

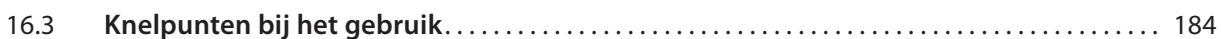

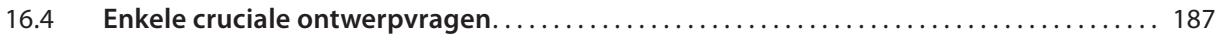

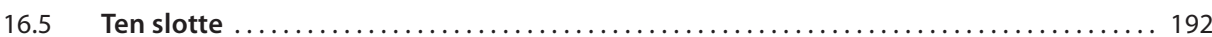

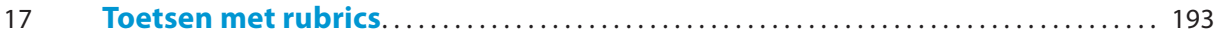

Paul van den Bos, Carel Burghout en Desirée Joosten-ten Brinke

17.1 Definities en soorten . . . . . . . . . . . . . . . . . . . . . . . . . . . . . . . . . . . . . 194

17.2 Rubrics voor formatief én summatief toetsen. ............................ 199

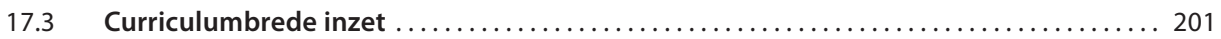

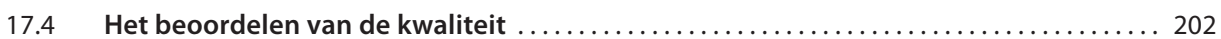

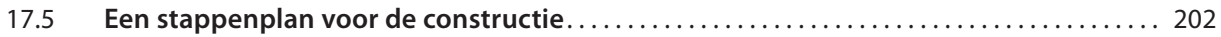

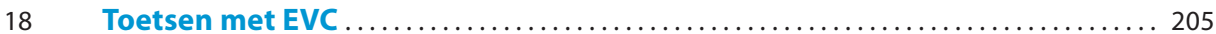

Ruud Klarus en Desirée Joosten-ten Brinke

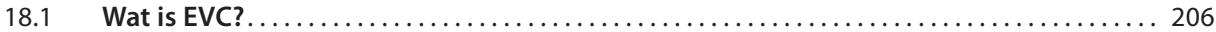

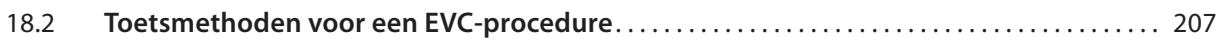

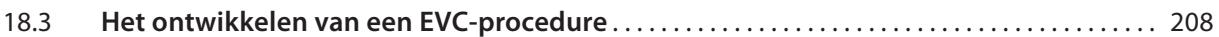

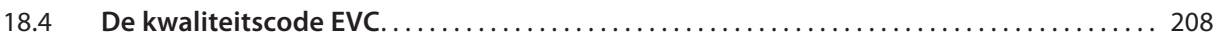

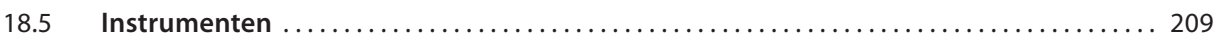

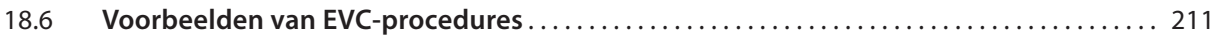

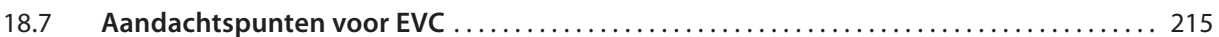

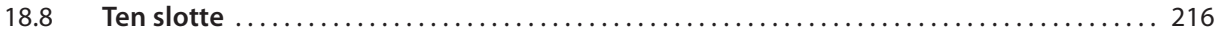

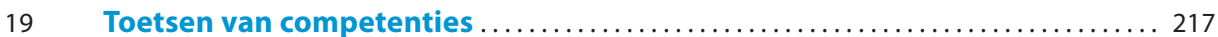

Judith Gulikers en Niek van Benthum

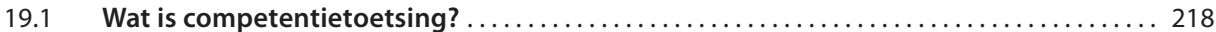

19.2 De meerwaarde van competentietoetsing ............................... 219

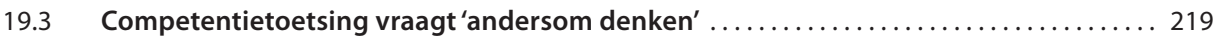

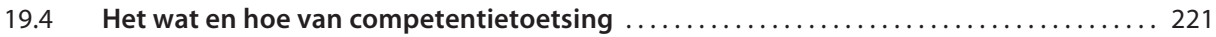

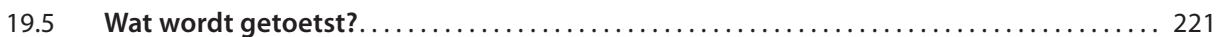

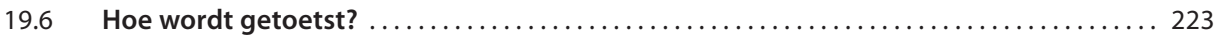

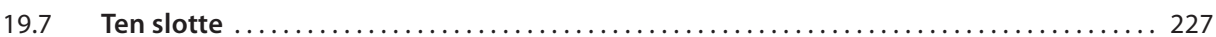

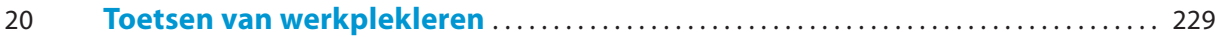

Marcel van der Klink en Jo Boon

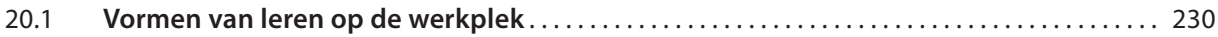

20.2 Dilemma's en problemen in werkplekleren .................................. 231

20.3 Instrumenten voor het beoordelen van werkplekleren $\ldots \ldots \ldots \ldots \ldots \ldots \ldots \ldots \ldots \ldots \ldots \ldots \ldots$

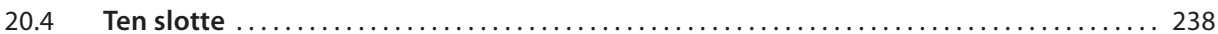


21 Toetsen van onderzoekvaardigheden

Quinta Kools en Ilona Mathijsen

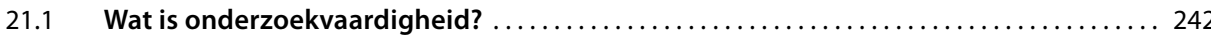

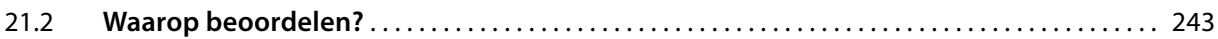

21.3 Instrumenten voor beoordeling $\ldots \ldots \ldots \ldots \ldots \ldots \ldots \ldots \ldots \ldots \ldots \ldots \ldots \ldots \ldots \ldots$

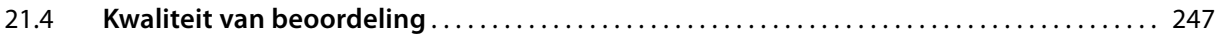

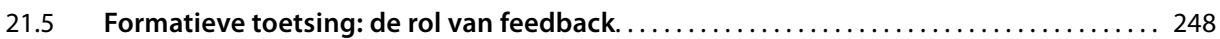

22 Toetsen van academische vaardigheden $\ldots \ldots \ldots \ldots \ldots \ldots \ldots \ldots \ldots \ldots \ldots \ldots$

Albert Pilot

$22.1 \quad$ Kenmerkende competenties voor het hoger onderwijs................. 252

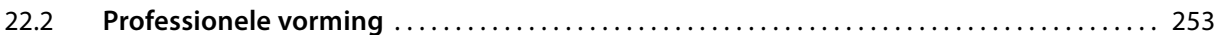

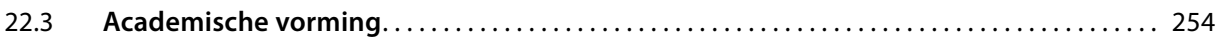

22.4 Werkwijze om geschikte toetsvormen te selecteren $\ldots \ldots \ldots \ldots \ldots \ldots \ldots \ldots \ldots \ldots \ldots 255$

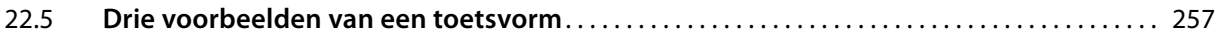

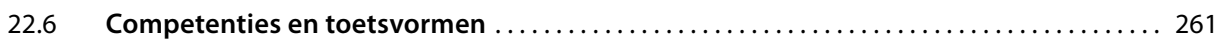

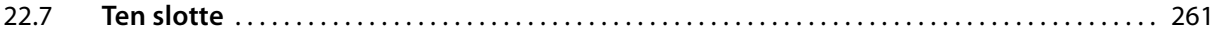

23 Toetsen van schriftelijke werkstukken....................... 263 Sjoerd Romme

$23.1 \quad$ Onbetrouwbaarheid en terugkoppelingseffecten $\ldots \ldots \ldots \ldots \ldots \ldots \ldots \ldots \ldots \ldots \ldots 264$

23.2 Beoordelingscriteria: wat wordt beoordeeld? ......................... 265

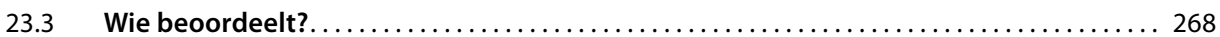

$23.4 \quad$ Hoe wordt getoetst? De afstudeerkring als voorbeeld $\ldots \ldots \ldots \ldots \ldots \ldots \ldots \ldots \ldots \ldots 270$

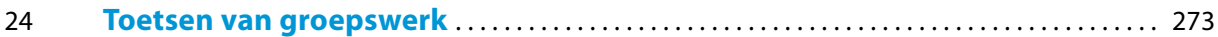

Anneke Bax, Jacob Perrenet en Henk van Berkel

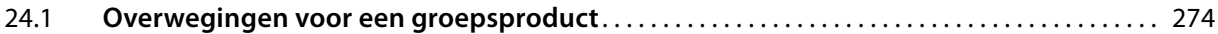

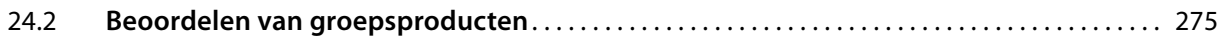

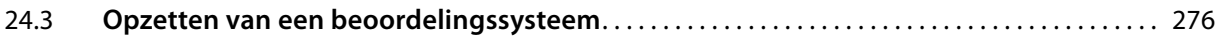

24.4 Methoden voor beoordeling: het betrekken van medestudenten.............. 280

$24.5 \quad$ Uitwerking van enkele beoordelingsmethoden $\ldots \ldots \ldots \ldots \ldots \ldots \ldots \ldots \ldots \ldots \ldots 281$

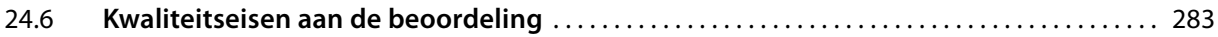

Beoordelaarseffecten $\ldots \ldots \ldots \ldots \ldots \ldots \ldots \ldots \ldots \ldots \ldots \ldots \ldots \ldots \ldots \ldots \ldots \ldots \ldots . \ldots 287$

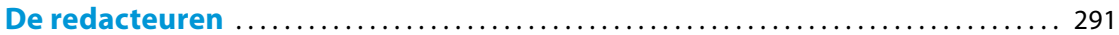

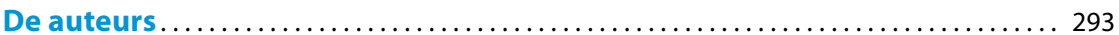


